ROCZNIK ADMINISTRACJI PUBLICZNEJ 2020 (6)

ARTYKUŁY / ARTICLES

Nauki o polityce i administracji

Political and administrative science

ARTUR SZKLARSKI ${ }^{1}$

\title{
Kulisy rosyjskiej polityki wobec Republiki Czeczenii i jej konsekwencje
}

\section{Wprowadzenie}

Kaukaz ma duże znaczenie geostrategiczne - znajduje się pomiędzy Azją i Europą oraz Morzem Czarnym i Kaspijskim². Obserwując zmagania mocarstw - działania Związku Radzieckiego i Federacji Rosyjskiej można zauważyć, że sytuacja na Kaukazie jest determinantą polityki regionalnej i globalnej3. Bezpieczeństwo przesyłu ropy naftowej z Baku do Noworosyjska było dla Rosjan kluczową kwestią. Surowiec transportowano przez Czeczenię i Dagestan z Azerbejdżanu do Rosji, na terytorium Czeczenii znajdowało się 150 z 1330 kilometrów rurociągu ${ }^{4}$. Destabilizacja Czeczeni groziłaby zakłóceniem dostaw, a trudna sytuacja Rosjan w latach 90. sprawiła, że wybudowanie omijających Czeczenię nowych rurociągów było sporym wydatkiem ${ }^{5}$.

Dostęp Związku Radzieckiego do Morza Kaspijskiego był regulowany przez dwustronne porozumienia z Iranem. Po 1991 roku Azerbejdżan, Kazachstan i Turkmenistan upomniały się o swoje prawa ${ }^{6}$. Konflikt intere-

1 Artur Szklarski, Instytut Nauk o Polityce i Administracji, Uniwersytet Pedagogiczny im. Komisji Edukacji Narodowej w Krakowie.

2 K. Iwańczuk, Geopolityka Kaukazu w: K. Iwańczuk, T. Kapuśniak (red.), Region Kaukazu w stosunkach międzynarodowych, Lublin 2008, s. 15.

3 J. O'Loughlin, V. Kolossov, J. Radvanyi, The Caucasus in a Time of Conflict, Demographic Transition and Economic Change, „Eurasian Geography and Economics”, nr 2 (2007), Oxfordshire, s. 135.

4 Minenergy.gov.az/en/neft/baki-novorossiysk-neft-kemeri (07.08.2020).

5 J. Szukalski, Konflikt w Czeczenii i jego wptyw na sytuację $w$ regionie Kaukazu w: K. Iwańczuk, T. Kapuśniak (red.), Region Kaukazu w stosunkach międzynarodowych, Lublin 2008, s. 145; P. Zajac: Geopolityczne znaczenie Czeczenii w polityce Federacji Rosyjskiej, geopolityka.net/geopolityczne-znaczenie-czeczenii-w-polityce-federacji-rosyjskiej (07.08.2020).

6 W. Gierańczyk, Międzynarodowe uwarunkowania pozyskiwania ropy naftowej w rejonie kaspijskim, „Prace Komisji Geografii Przemysłu”, nr 10 (2010), Kraków, s. 133-134. 
sów miał być rozwiązany na jeden $\mathrm{z}$ dwóch sposobów, które spotkały się z największym uznaniem. Według pierwszego, państwa otrzymałyby po 20 procent linii brzegowej, drugi zakładał proporcjonalny podział - Azerbejdżan, Rosja i Turkmenistan dostałyby po 19 procent, Kazachstanowi przypadłoby 30, a Iranowi $13^{7}$. Destabilizacja Dagestanu (leżącej na Kaukazie rosyjskiej republiki, graniczącej od zachodu z Czeczenią), który w pewnym momencie został przejęty przez islamskich separatystów, a nawet jego oderwanie od terytorium Rosji, poddawałoby pod wątpliwość zasadność takiego podziału (Rosjanie straciliby 200 kilometrów linii brzegowej - ich udział wynosiłby kilka procent) ${ }^{8}$. Dagestan był drogą do Morza Kaspijskiego, na którego dnie znajdowały się złoża ropy i gazu9. Kontrola nad Czeczenią nie wiązała się tylko z wpływami w republice - oznaczała kontrolowanie całego Północnego Kaukazu. Mocarstwowa polityka Rosji wymagała podjęcia o nią trudnej, ale koniecznej walki ${ }^{10}$.

Ówczesny minister spraw zagranicznych Federacji Rosyjskiej - Andriej Kozyriew, w latach 1992-1993 głosił politykę opartą na wartościach demokratycznych. Rosja zwracała się ku Zachodowi dążąc do wzajemnej pomocy i współpracy ${ }^{11}$. Jednak ostatecznie nie zaakceptowała roli „młodszego partnera" w relacjach ze Stanami Zjednoczonymi. Następca Kozyriewa Jewgienij Primakow wdrażał założenia neorealizmu politycznego mające przywrócić mocarstwowość państwa. Najważniejszym celem stało się utrzymanie strefy wpływów na obszarze postsowieckim. Realpolitik Primakowa odrzucał postawy moralne, które mogłyby przeszkadzać w realizacji zasadniczych interesów Rosji ${ }^{12}$.

Celem niniejszego artykułu jest przedstawienie nieoficjalnych metod działania wykorzystanych przez Kreml w celu odbudowy jego wpływów na Północnym Kaukazie. Główną tezą jest stwierdzenie, że Rosja podjęła daleko idącą zakulisową działalność względem Czeczenii, dążąc do wyeliminowywania władzy niewygodnej dla Kremla i zastąpienia jej taką, na którą Rosjanie mogliby wywierać silniejszy wpływ. Z tezy głównej wynikają tezy szczegółowe. Pierwsza z nich zakłada, że Moskwa wykorzystała swoje służby specjalne do przeprowadzenia operacji mających wpłynąć na na-

7 Ibidem.

8 E.W. Anderson, Global Political Flashpoint. An Atlas of Conflict, Nowy Jork 2000, s. 93.

9 Giovanni Valvo: Dagestan: Geopolityczne znaczenie najbardziej wysuniętej na potudnie republiki Rosji, geopolityka.org/komentarze/1321-dagestan-geopolityczne-znaczenie-najbardziej-wysunietej-na-poludnie-republiki-rosji (07.08.2020).

10 P. Zajac: Geopolityczne znaczenie Czeczenii w polityce Federacji Rosyjskiej, geopolityka.net/geopolityczne-znaczenie-czeczenii-w-polityce-federacji-rosyjskiej (07.08.2020).

11 P. Kozłowski, Obszar postradziecki w oficjalnych strategiach Federacji Rosyjskiej i Rady ds. Polityki Zagranicznej i Obronnej w: Z. J. Winnicki, W. Baluk, G. Tokarz (red.), Wybrane problemy badań wschodnich, Wrocław 2007, s. 259.

12 Ibidem; P. Zajac: Geopolityczne znaczenie... 
stroje społeczne. Druga potwierdza istnienie dowodów niezważania przez rosyjskie władze na życie i zdrowie swoich obywateli, jeśli moskiewska polityka zagraniczna tego wymaga. Zastosowana w niniejszym opracowaniu metoda badawcza polega na opisie, analizie i logicznym uporządkowaniu znanych faktów, twierdzeń, wniosków i rozumowań.

\section{Następstwa I wojny czeczeńskiej}

Konflikt z Czeczenią w zamyśle Rosjan miał być „krótką i zwycięską wojenką" ${ }^{13}$ tak też go nazywali - mającą podnieść coraz bardziej spadające notowania prezydenta Borysa Jelcyna, który potrzebował wzmocnienia pozycji przed wyborami. Krystyna Kurczab-Redlich ${ }^{14}$ uważa, że zapomniana I wojna czeczeńska rozpoczęła się druzgocącą klęską rosyjskich wojsk. Rosjanie zostali wprowadzeni do stolicy kraju Groznego, głównie w formie jednostek pancernych i niedoświadczonych w boju młodych żołnierzy. Jesienią 1993 roku czołgi wjechały w wąskie ulice miasta, ale nie mogąc podnieść lufy powyżej 30 stopni, ze względu na brak właściwej osłony piechoty okazały się bezskuteczne przeciwko spodziewającym się ataku wojskom przeciwnika. Zdaniem Kurczab-Redlich, Czeczeńcy byli doskonale przygotowani również dlatego, że byli dobrymi żołnierzami walczyli z Rosjanami już od ponad 400 lat. Wskazane okoliczności doprowadziły do rzezi wysłanych na pewną śmierć Rosjan ${ }^{15}$.

Według Kurczab-Redlich wojna została wygrana przez Czeczenów militarnie byli zdecydowanie skuteczniejsi od niedożywionych, źle traktowanych przez przełożonych i całkowicie nieprzygotowanych do walki rosyjskich poborowych. Czeczenia odzyskała niepodległość. Jednak konflikt spowodował szereg późniejszych klęsk pod względem politycznym. Trzyletnie zmagania wojenne zwieńczono podpisaniem rozejmu w Chasawjurcie 31 sierpnia 1996 roku $^{16}$.

W 1997 roku miało dojść do drugich wolnych wyborów w historii Czeczenii, ale zanim nastąpiły, Kreml starał się przedstawić światu możliwie najbardziej niekorzystny wizerunek czeczeńskiego narodu. Zamierzał udo-

13 W. Jurasz, K. Kurczab-Redlich, op. cit.

14 Dziennikarka, reportażystka, wieloletnia korespondentka polskich mediów w Rosji i autorka szeregu książek oraz filmów dokumentalnych, m.in. wyczerpująco opisujących wojnę w Czeczenii.

15 Szerzej: K. Kurczab-Redlich, Wowa, Wołodia, Władimir. Tajemnice Rosji Putina, Warszawa 2016; szerzej: K. Kurczab-Redlich, Głowa o mur Kremla. Nowe fakty, Warszawa 2012; szerzej: K. Kurczab-Redlich, Pandrioszka, Poznań 2000; W. Jurasz, K. Kurczab-Redlich, Podcast, \#97 Polityka z ludzka twarza: Krystyna Kurczab-Redlich, odc. 97; storytel.com/pl/pl/books/1077943-podcast-97-polityka-z-ludzka-twarza-krystyna-kurczab-redlich (01.02.2020).

16 K. Kurczab-Redlich, Wowa,..., op. cit.; K. Kurczab-Redlich, Głowa..., op. cit.; K. Kurczab-Redlich, Pandrioszka, op. cit.; W. Jurasz, K. Kurczab-Redlich, op. cit. 
wodnić, że skoro Rosja zaczęła z nim walczyć, musiała mieć pretekst, żeby walkę rozpocząć i powody, żeby ją prowadzić. Kurczab-Redlich zwraca uwagę, że terroryzm nie był wtedy popularnym tematem - lekceważono niebezpieczeństwo do czasu zamachów na World Trade Center. Jak jednak twierdzi, Rosjanie wykorzystali zagrożenie terroryzmem jako pretekst do podsycenia antyczeczeńskich nastrojów i ingerencji w sprawy Czeczenii. Skonstruowali cały proceder porwań, mających miejsce pomiędzy zakończeniem I wojny czeczeńskiej a następnymi wyborami prezydenckimi. Zdecydowana większość z tych porwań dotyczyła bardzo znanych z rosyjskiego punktu widzenia ludzi, ale nie tylko uprowadzono także np. czterech Anglików i Irlandczyka, których zadaniem było założenie pierwszej sieci komórkowej w Czeczenii. Jej zdaniem nie porywano dla okupu - wysyłano do świata sygnał, że porwania były następstwem różnych przyczyn, ponieważ ich nie wskazywano wszyscy uprowadzeni cudzoziemcy zostali brutalnie zamordowani, a ich odcięte głowy odnaleziono w worku przy jednej z głównych dróg. Kurczab-Redlich konstatuje, że takie działania miały zohydzić wizerunek Czeczena na świecie, w końcu zabijano zachodnich obywateli ${ }^{17}$.

Kurczab-Redlich zwraca uwagę, że Czeczeni również wpływali negatywnie na swój wizerunek poprzez postacie takie jak Sałman Radujew, czy Szamil Basajew, który był jej zdaniem potężniejszy. Zauważa, że w Czeczenii mówi się o nich z pewną wstrzemięźliwością. Przykładowo Basajew $\mathrm{w}$ trakcie I wojny wykazał się wielką odwagą, będąc jednym $\mathrm{z}$ głównych komendantów polowych rebeliantów i jest postrzegany jako patriota walczący o uniezależnienie Czeczenii od Rosji. Przegrał jednak wewnętrzną walką o znaczenie w państwie z wybranym w 1997 prezydentem Czeczenii Asłanem Maschadowem, wcześniejszym szefem sztabu sił czeczeńskich. Zamiast objąć najważniejszy urząd w państwie pełnił kolejno funkcje wicepremiera i premiera ${ }^{18}$.

14 czerwca 1995 roku Basajew uwięził około 1500 (głównie cywilnych) zakładników w rosyjskim mieście Budionnowsk, w trakcie ich odbijania śmierć poniosło 129 osób $^{19}$. Przerywane negocjacjami kilkudniowe walki doprowadziły do zwolnienia zakładników, $\mathrm{w}$ zamian za tymczasowe zawieszenie broni w Czeczenii, a za Basajewem wysłano w Rosji list gończy. $\mathrm{W}$ maju tego samego roku przeprowadzono precyzyjny atak lotniczy na jego dom w Wiedieno, w którym zabito 11 członków jego najbliższej rodziny $^{20}$. Basajew został uznany za jednego z najgroźniejszych światowych terrorystów nie tylko przez Rosję, ale także przez ONZ, Komisję Europej-

17 Ibidem.

18 Ibidem.

19 Rferl.org/a/after-25-years-budyonnovsk-hostage-crisis-seen-as-horrific-harbinger-of-terror/30668760.html (02.02.2020).

20 Zobacz: M. Kuleba, Szamil Basajew: rycerski etos a powinność żołnierska, Warszawa 2007. 
ską i Departament Stanu USA ${ }^{21}$. Sam przypisał sobie uczestnictwo w wielu zamachach, m.in. w przeprowadzeniu 9 maja 2004 roku ataku na świętujących w Groznym dzień zwycięstwa, w którym został zabity m.in. Achmad Kadyrow - prorosyjski prezydent Czeczenii. 17 września tego samego roku w opublikowanym w Internecie liście przyznał się do wzięcia około 1200 zakładników w szkole w Biesłanie ${ }^{22}$. W trakcie szturmu specnazu śmierć poniosło 330 osób, w tym 186 dzieci, a ponad 700 odniosło obrażenia, z czego 450 zostało hospitalizowanych ${ }^{23}$. Europejscy dziennikarze przewidywali, że ofiar może być ponad 400, ze względu na 176 osób, które zaginęły ${ }^{24}$. Zastępca prokuratora generalnego Siergiej Fridinski przekazał, że żołnierze sił specjalnych wyeliminowali 31 z 32 porywaczy, natomiast jeden schwytany został zabity przez ojców zakładników w trakcie transportu do szpitala ${ }^{25}$. Władimir Putin oświadczył, że w akcji zginęło 11 żołnierzy specnazu a kilkudziesięciu zostało rannych ${ }^{26}$. Basajew przyznał się także do równoczesnego przeprowadzenia zamachów bombowych 24 sierpnia 2004 roku na dwa samoloty pasażerskie, w których zginęło 90 osób oraz do detonacji na stacji metra w Moskwie 31 sierpnia tego samego roku, w której zginęło 10 osób ${ }^{27}$. W sierpniu 1999 roku Basajew wspólnie z arabskim bratem krwi Chattabą pokierował oddziałami islamskich bojowników, które wkroczyły do Dagestanu, a sam Basajew został ogłoszony przywódcą republiki islamskiej, co było jedną z przyczyn rozpoczęcia II wojny czeczeńskiej ${ }^{28}$.

W późniejszych latach wykazano, że od 1991 roku Szamil Basajew był współpracownikiem GRU (rosyjskiego wywiadu wojskowego) ${ }^{29}$, a jego działania dotyczące np. zamachu w Biesłanie były dokładnie powiązane terminami z potrzebami Kremla ${ }^{30}$. Kurczab-Redlich wnioskuje, że Rosjanie w istocie wyhodowali sobie terroryzm. Jej zdaniem takie spojrzenie powszechnie odnosi się także do np. najwcześniejszych przyczyn powstania Państwa Islamskiego. Tłumaczy, że w ISIS było bardzo wielu ludzi, którzy byli dziwnym trafem szybko zwalniani z rosyjskich więzień, chociaż normalną praktyką w Rosji jest wypuszczanie terrorystów jedynie, gdy są już

21 Web.archive.org/web/20131128153520/http://www.un.org/sc/committees/1267/ aq_sanctions_list.shtml (02.02.2020); eur-lex.europa.eu/LexUriServ/LexUriServ.do?uri=CELEX:32003R1607:EN:HTML (02.02.2020); web.archive.org/web/20080216090707/ http://usinfo.state.gov/ei/archive/2004/jan/07-157373.html (02.02.2020).

22 Edition.cnn.com/2013/09/09/world/europe/beslan-school-siege-fast-facts/index.html (02.02.2020).

23 Ibidem.

24 Zobacz: M. Kuleba, op. cit.

25 Edition.cnn.com/2013/09/09/world/europe/beslan-school-siege-fast-facts/index.html (02.02.2020).

26 Zobacz: M. Gessen, Putin. Człowiek bez twarzy, Warszawa 2012.

27 Edition.cnn.com/2004/WORLD/europe/09/17/russia.beslan (02.02.2020).

28 Szerzej: M. Kuleba, op. cit.

29 K. Kurczab-Redlich, Wowa,..., op. cit., s. 315-375.

30 Ibidem, s. 352. 
martwi. Uważa się, że więźniowie nie wychodzili przypadkiem wielu z nich okazało się być inicjatorami Państwa Islamskiego. W Czeczenii Rosjanie przekształcili ruch narodowowyzwoleńczy w ruch dżihadystyczny. Kurczab-Redlich zauważa, że na początku nie było tam śladu wahabizmu i nikt o nim nawet nie mówił (jednej z wielu szkół islamu sunnickiego, określanej jako skrajnie fundamentalistyczna). Natomiast już w 1998 roku w Czeczenii było wielu rzadko wcześniej spotykanych ludzi z brodami, jednocześnie wahabizm stał się niepokojącym tematem rozmów ${ }^{31}$. Dowiedziono, że Adam Denijew, który założył pierwszą organizację wahabicką w Czeczenii, działał w ścisłym związku z FSB (rosyjską federalną służbą bezpieczeństwa $)^{32}$. Sąd udowodnił, że w czerwcu 1996 roku Denijew zorganizował zabójstwo pracowników Międzynarodowego Czerwonego Krzyża. Kurczab-Redlich jest przekonana, że intencją sprawcy było pokazanie światu czeczeńskiej bezwzględności. Uważa, że Rosjanie przez cały czas sprytnie rozgrywali sytuację w Czeczenii na własną korzyśćc ${ }^{33}$.

W centrum Moskwy na Placu Łubiańskim znajduje się okryta złą sławą Łubianka, która od 1917 roku jest synonimem sowieckich, a następnie rosyjskich służb bezpieczeństwa - mieściły się w niej kolejno zarządy Czeka, NKWD, KGB i obecnie FSB. W trakcie stalinowskiego terroru zamordowano tam licznych więźniów politycznych; martyrologia zmarłych tam Polaków została upamiętniona po 1990 roku napisem na jednej z tablic na Grobie Nieznanego Żołnierza w Warszawie. Naprzeciwko budynku 30 października 1990 roku, z inicjatywy rosyjskiej organizacji pozarządowej „Stowarzyszenie Memoriał”, odsłonięto Kamień Sołowiecki przywieziony z Wysp Sołowieckich (znajdował się tam łagier specjalnego przeznaczenia). Pomnik upamiętnia ofiary represji politycznych totalitarnego reżimu i gułagu w Związku Radzieckim. Jest znanym miejscem składania im hołdu Bronisław Komorowski jeszcze jako Marszałek Sejmu, w trakcie wizyty zagranicznej w maju 2010 roku, złożył w tym miejscu kwiaty ${ }^{34}$.

W lipcu 1997 roku na czele sławnej Łubianki stanął Władimir Władimirowicz Putin, już wtedy dysponujący niemałym zapleczem wywiadowczym potrzebnym do manipulacji sytuacją w Czeczenii, którego zdobycie zajęło mu kilka lat. Putin od 1986 do 1990 roku pracował w KGB w Dreźnie, a jego zadaniem było werbowanie praktycznie wszystkich, którzy się do tego nadawali. Ze względu na stosunkowo nienajlepsze efekty funkcjonariuszy na tamtym obszarze, do jego niewielu pozytywnych działań należała przede

31 Britannica.com/topic/wahhabi (03.02.2020).

32 K. Kurczab-Redlich, Wowa,..., op. cit., s. 295-302; A. Zakajew, Ujarzmić lub wytrzebić, rękopis $\mathrm{z}$ archiwum Kurczab-Redlich.

33 K. Kurczab-Redlich, Wowa,..., op. cit.; K. Kurczab-Redlich, Głowa..., op. cit.; K. Kurczab-Redlich, Pandrioszka, op. cit.; W. Jurasz, K. Kurczab-Redlich, op. cit.

34 Cr.middlebury.edu/public/russian/bulgakov/public_html/nkvd.html (04.02.2020); wprost.pl/194718/marszalek-komorowski-odwiedzi-grob-gen-okulickiego.html (04.02.2020). 
Kamień Sołowiecki na tle Łubianki

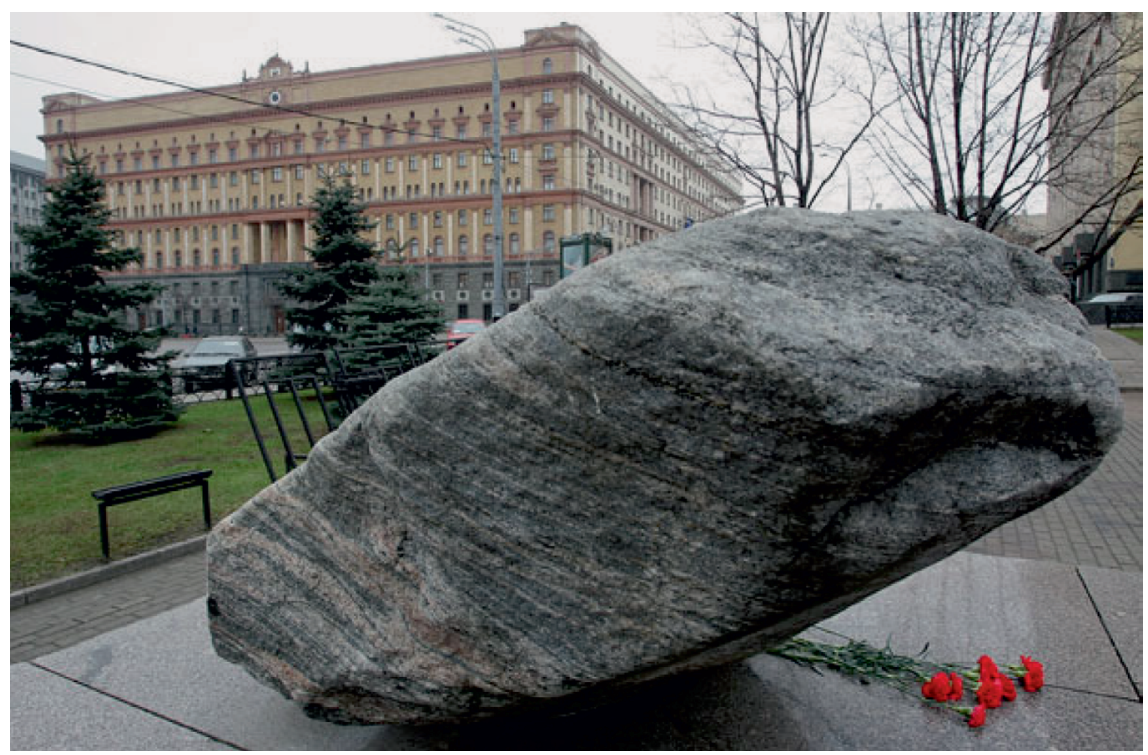

Źródło: fakty.interia.pl/swiat/news-12-godzin-odczytywania-nazwisk-ofiar-stalinizmu,nId,1912229 (04.02.2020).

wszystkim praca ze studentami dreznieńskiej politechniki, wśród których wyławiał najczęściej przedstawicieli Trzeciego Świata i Bliskiego Wschodu. Oprócz tego, że udawało mu się ich pozyskiwać, Putin przede wszystkim zdobywał duże rozeznanie wśród możliwości werbunkowych na tych terenach. Objął szefostwo nad Łubianką mając już do dyspozycji pokaźny dossier tamtejszych agentów KGB, dodatkowo posiadając nazwiska potencjalnie przydatnych kandydatów. Kurczab-Redlich zauważa, że w latach 1997-1998 nagle do Czeczenii bez żadnych przeszkód trafiali brodaci ludzie z Iranu, Syrii i Zjednoczonych Emiratów Arabskich, którzy byli wyposażeni w ogromne ilości pieniędzy. Z nadzwyczajną łatwością udał im się werbować spośród biedujących po wojnie i bezrobotnych Czeczenów. Zdaniem autorki, większość porywaczy wywodzi się z nowo-pozyskanych grup ${ }^{35}$.

Kurczab-Redlich widziała wybory w 1997 roku, które zrobiły na niej niesłychane wrażenie. Tłumy Czeczenów otoczonych gruzami ruszyły do lokali wyborczych, żeby wybrać na prezydenta Maschadowa (komendanta wojskowego, który był głównym dowódcą odpowiedzialnym za wygraną w I wojnie czeczeńskiej). Z jej obserwacji wynika, że Maschadow zmierzał do pokoju, a nawet do układów z Kremlem. Szamil Basajew, który wypowiedział mu walkę, polegał na cichym wsparciu FSB. W jego obozie znajdowali się m.in. byli porywacze, ich celem było możliwie jak najdotkliwsze szkodzenie Maschadowowi. Zdaniem Kurczab-Redlich, Maschadow, który

35 K. Kurczab-Redlich, Wowa,.., op. cit.; K. Kurczab-Redlich, Głowq..., op. cit.; K. Kurczab-Redlich, Pandrioszka, op. cit.; W. Jurasz, K. Kurczab-Redlich, op. cit. 
był przedstawicielem opozycji demokratycznej przegrał, ponieważ działał w granicach prawa. Uważa się, że okazał się za słaby - obawiał się zlecić zamordowanie Basajewa, nie chcąc wywołać następnej wojny tym razem domowej ${ }^{36}$.

\section{Seria zamachów bombowych w Rosji}

Po tym jak Putin został premierem, doszło do serii zamachów bombowych na budynki mieszkalne w czterech rosyjskich miastach, mających miejsce w ciągu dwóch tygodni września 1999 roku. Śmierć poniosło łącznie 308 osób, a 988 zostało rannych ${ }^{37}$. Kreml z Putinem na czele przypisał odpowiedzialność czeczeńskim separatystom. Dla Rosjan te wydarzenia stanowiły casus belli do poprzedzonej tygodniem bombardowań z powietrza, wszczętej przez Putina 11 października 1999 roku II wojny czeczeńskiej. Zamachy i wspomniana już ofensywa lądowa Basajewa w Dagestanie zostały potępione przez Maschadowa ${ }^{38}$. Po trzech miesiącach od wybuchów, Putin przejął prezydenturę od Jelcyna, a w maju 2000 roku z łatwością wygrał w wyborach na urząd prezydenta ${ }^{39}$.

4 września 1999 roku przed budynkiem na wojskowym osiedlu mieszkaniowym, w mieście Bujnaksk w Dagestanie, eksplodował umieszczony na ciężarówce ładunek wybuchowy. Zginęły 64 osoby, a 146 odniosło obrażenia ${ }^{40}$. Moskiewskie władze natychmiast odpowiedzialnością obarczyły czeczeńskich separatystów. W tym samym dniu w Bujnaksku znaleziono zaparkowany obok szpitala wojskowego i budynków mieszkalnych pojazd ZIŁ-130 z 2706 kilogramową bombą. Czujność mieszkańców pozwoliła udaremnić zamach - zadziałali obywatele, nie służby. 8 września tego samego roku doszło do eksplozji około 400 kilogramów materiałów wybuchowych znajdujących się na parterze 9-piętrowego bloku w południowo-wschodniej dzielnicy Moskwy. Zginęło 100 osób, 690 zostało rannych, a 108 mieszkań uległo zniszczeniu ${ }^{41}$. Do jednej z rosyjskich agencji informacyjnych zadzwonił anonim, który przekazał, że zamach stanowi odwet za zbombardowanie czeczeńskich i dagestańskich miasteczek. 13 września duży ładunek wybuchowy eksplodował w 8-piętrowym budynku, w po-

36 Ibidem.

37 Henryjacksonsociety.org/wp-content/uploads/2018/06/1412-Whos-BlowingUp-Russia.pdf, s. 3 (02.02.2020).

38 Szerzej: J. Felsztinski, W. Pribyłowski, Korporacja zabójców. Rosja, KGB i prezydent Putin, Warszawa 2008; szerzej: A. Litwinienko, J. Felsztinski, Wysadzić Rosje, Poznań 2007.

39 Szerzej: A. Zechenter, Operacja „Hiroszima”, czyli Putin przejmuje władze, „Dziennik Polski”, nr 30.09 (2011), Kraków.

40 Henryjacksonsociety.org/wp-content/uploads/2018/06/1412-Whos-BlowingUp-Russia.pdf, s. 3 (02.02.2020).

41 Ibidem. 
łudniowej części Moskwy, przy ulicy Kaszyrskoje Szosse. Budynek został zniszczony, zginęło 125 osób, a 7 odniosło obrażenia ${ }^{42}$. Do wybuchu doszło o 5:00 rano; na ten dzień zaplanowano żałobę w celu uczczenia zmarłych w wyniku poprzedniego zamachu. Do następnej eksplozji doszło 16 września w południowej Rosji, pod 9-piętrowym blokiem w Wołgodońsku. Zginęło 19 osób, a 145 zostało rannych ${ }^{43}$.

FSB i Ministerstwo Spraw Wewnętrznych 14 września wystosowały oświadczenie dotyczące dotychczasowych zamachów. Ich przedstawiciel Szef Centrum Kontaktów Publicznych FSB - generał Aleksander Zdanowicz powiedział, że śledczy są pewni, iż seria wybuchów jest częścią „(...) operacji terrorystycznej zakrojonej na wielką skalę, wszczętej przez partyzantów Basajewa i Chattaba w celu wsparcia ich akcji militarnej w Dagestanie" ${ }^{\prime 4}$. Jego stanowisko potwierdził Wiceminister Spraw Zagranicznych - Igor Zubow: „Możemy już stwierdzić z całą pewnością, że za zamachami bombowymi stoją Basajew i Chattab" ${ }^{35}$. Ich przekaz mijał się z obwieszczeniem naczelnika Głównego Urzędu Zwalczania Przestępczości Zorganizowanej Władimira Kozłowa, który następnego dnia przekazał, że „zidentyfikowano kilka osób zamieszanych w te ataki terrorystyczne"46. Po czym wyjaśnił, iż ma na myśli działającą w Moskwie i rejonach ościennych grupę terrorystyczną - nie powiedział nic o Czeczenii i Dagestanie ${ }^{47}$.

17 września odbyło się nadzwyczajne posiedzenie Rady Federacji, z udziałem szefów ministerstw siłowych, w trakcie którego zatwierdzono projekt utworzenia w rosyjskich regionach „obywatelskich rad bezpieczeństwa”. Jej przewodniczący - Jegor Strojew zwrócił uwagę, że senatorowie chcieli „(...) dokonać politycznej oceny wydarzeń i zaproponować konkretne środki ekonomiczne i społeczne w strefie konfliktu, w tym środki wsparcia dla cywilów i armii”48. Dodał także, iż „Eksplozja w Wołgodońsku umocniła senatorów w przekonaniu, że potrzebne są bardziej zdecydowane i surowsze środki walki z terroryzmem"49. Tym samym Strojew bezpośrednio nie obwinił Czeczenów o przeprowadzenie zamachów, jednak zasugerował związek pomiędzy „walką z terroryzmem” a „strefą konfliktu” w Dagestanie. Premier Putin zaprezentował raport, w którym utworzenie kordonu sanitarnego na przestrzeni całej długości granicy rosyjsko-czeczeńskiej oraz intensyfikację ostrzału artyleryjskiego i bombardowań Czeczenii przedstawił jako „środki obrony przed terroryzmem”. W ten sposób Republika Czeczeńska została przez niego uznana za winną zamachów bombo-

42 Ibidem.

43 Ibidem, s. 4; A. Litwinienko, J. Felsztinski, op. cit.

44 A. Litwinienko, J. Felsztinski, op. cit., s. 154.

45 Ibidem.

46 Ibidem.

47 Ibidem; J. Felsztinski, W. Pribyłowski, op. cit.

48 A. Litwinienko, J. Felsztinski, op. cit., s. 163.

49 Ibidem. 
wych; apelował o wszczęcie działań odwetowych o charakterze zbrojnym. Po zamknięciu posiedzenia, Putin przekazał, że członkowie Rady Federacji uznali za stosowne podjęcie działań „o najbardziej zdecydowanym charakterze" ${ }^{50}$, które zostaną przez rząd powzięte, w celu zażegnania sytuacji na północnym Kaukazie; wraz z propozycją objęcia Czeczenii kwarantanną. Na pytania dziennikarzy odpowiedział, że ataki poprzedzające są i będą wymierzane w bazy bandytów w Czeczenii, ale Rada nie przeprowadziła dyskusji o wprowadzeniu rosyjskich sił zbrojnych ${ }^{51}$.

Wieczorem 22 września Aleksiej Kartofielnikow mieszkający w 11-piętrowym bloku pod adresem Nowosiołowska 14/16 w półmilionowym Riazaniu, leżącym 200 kilometrów od Moskwy dostrzegł trzech podejrzanych ludzi wnoszących z samochodu do piwnicy jednego z budynków przy ulicy Nowosiołowskiej duże worki. Wezwał milicję, która zjawiła się - w zależności od wersji - po 30-35 minutach i przeprowadziła pospieszną ewakuację mieszkańców (zabroniono im zabierania czegokolwiek). Milicjanci weszli do piwnicy, relacjonując później mediom: „Leżący na wierzchu worek był nacięty i wystawało z niego jakieś urządzenie elektroniczne: widzieliśmy kable owinięte taśmą oraz zegar. Wybiegliśmy z piwnicy. Ja stanąłem na straży przy drzwiach, a moi ludzie pobiegli ewakuować mieszkańców"52. Po 15 minutach przyjechali saperzy z Ministerstwa Spraw Nadzwyczajnych, którzy rozbroili bombę. Zawartość trzech 50-kilogramowych worków z napisem „cukier” została przebadana i okazała się zawierać materiał wybuchowy (heksogen), a w jednym z nich znajdował się detonator. Wprowadzone natychmiastowo blokady drogowe okazały się być bezskuteczne (milicja kontrolowała wszystkie pojazdy wyjeżdżające z Riazania). 23 września władze poinformowały, że w mieście udało się udaremnić zamach terrorystyczny, a gazety pisały, że w workach był heksogen. W światowych mediach ukazywały się reportaże o Riazaniu, a premier Putin chwalił społeczeństwo za „absolutnie słuszną reakcję" ${ }^{53}$. Jednak wkrótce wyszło na jaw, że 22 września pracownica telekomunikacji nagrała międzymiastową rozmowę, w której kazano rozmówcom uważać na patrole milicji: „Wysiadajcie pojedynczo. Wszędzie są patrole" - ktoś z Moskwy wydawał polecenia poruszającym się samochodem przez Riazań ${ }^{54}$. Riazańska FSB otrzymała od niej nagranie, a będąc przekonaną, że kobieta namierzyła zamachowców, służba sprawdziła numer należał do FSB w Moskwie. Jednak władze nie poinformowały o prowadzeniu ćwiczeń, jedynie dziękowały mieszkańcom za czujność. Ponadto 24 września riazańskim służbom chcącym dokonać zatrzymania udało się ustalić miejsce pobytu terrorystów. Wtedy w telewizji ówczesny dyrektor FSB Nikołaj Patruszew oświadczył, że moskiewskie

50 Ibidem.

51 Ibidem.

52 A. Zechenter, op. cit.

53 Ibidem.

54 Ibidem. 
FSB przeprowadziło próbę, wyjaśniając, iż chciano sprawdzić stopień gotowości FSB w Riazaniu. W oficjalnym oświadczeniu FSB przekazało, że śladowe ilości heksogenu z poprzednich badań były przyczyną fałszywie dodatniego rezultatu pierwszego badania substancji ${ }^{55}$. Naczelnik pirotechników riazańskiego FSB Jurij Tkaczenko i jego współpracownicy twierdzili, że heksogenu u nich wcześniej nie badano, zatem nie było możliwości zanieczyszczenia ${ }^{56}$. Prokurator Generalny wszczą dochodzenie, jednak FSB nie udzieliło dostatecznych informacji, przez co śledztwo nie doprowadziło do konkretnych wyników i zamknięto je w kwietniu 2000 roku. Nieznane są oficjalne wyjaśnienia dlaczego FSB w Moskwie przeprowadziło powtórne badanie substancji i próbowało ją wysadzić, skoro wiedziało, że prowadzono ćwiczenia, a substancją był tylko cukier. Sprawę schwytanych terrorystów szybko utajniono. Do opinii publicznej nigdy nie przedostały się żadne dokumenty dotyczące ćwiczeń, których przeprowadzenie stało $\mathrm{w}$ sprzeczności z obowiązującym prawem i procedurami. Władze nie wytłumaczyły braku atrap zastąpionych przez sprawne detonatory. W wyniku ewakuacji, kilku mieszkańców budynku zmarło na zawał serca ${ }^{57}$.

Dane dotyczące ilości i rodzaju ładunków wybuchowych znalezionych po zamachach były różne. W Moskwie odnaleziono około 13 ton - 3-4 tony w bloku przy ulicy Borisowskije Prudy, 4 tony w dzielnicy Kapotnia i jeszcze więcej w dzielnicy Lublino. Jakiś czas później spostrzeżono, że z Niewinnomyskiego Kombinatu Chemicznego w Kraju Stawropolskim zniknęło 6 ton heptylu, czyli paliwa rakietowego, w skład którego wchodzi heksogen ${ }^{58}$. Była to ilość wystarczająca do wytworzenia 10 ton materiału wybuchowego, ale niemożliwe było ich wyprodukowanie w garażu, kuchni albo w podziemnym laboratorium - do przetworzenia takiej ilości heptylu trzeba byłoby wykorzystać magazyn wojskowy. Ciężarówki z załadowanymi workami zawierającymi gotową substancję - możliwe, że po okazaniu dokumentów musiały zostać wywiezione pod okiem wartowników. Transport takiej ilości ładunku wybuchowego wymagał sporo sprzętu i ludzi - ze względu na niemały rozmiar akcji, istniało duże ryzyko, że agenci kontrwywiadu wojskowego wykryją operację ${ }^{59}$.

Rosyjscy historycy Władimir Pribyłowski i Jurij Fielsztinski w książce pt. „Korporacja zabójców. Rosja, KGB i prezydent Putin” opisują jak podczas usiłowania wysadzenia bloku w Riazaniu doszło do schwytania dwóch funkcjonariuszy FSB. Znajdują się w niej także zeznania starszego porucznika Aleksieja W. Gałkina, które dowodzą udziału FSB w zamachach ${ }^{60}$.

55 A. Litwinienko, J. Felsztinski, op. cit., s. 189.

56 Ibidem, s. 190-191.

57 A. Zechenter, op. cit.; A. Litwinienko, J. Felsztinski, op. cit.; J. Felsztinski, W. Pribyłowski, op. cit.

58 A. Litwinienko, J. Felsztinski, op. cit., s. 145.

59 Ibidem.

60 J. Felsztinski, W. Pribyłowski, op. cit. 
$\mathrm{W}$ popularnym serwisie internetowym YouTube zachowały się ponadto wyświetlone na ogólnokrajowej antenie, tuż po ujęciu agentów FSB w Riazaniu, archiwalne materiały z rosyjskiej telewizji, w których naoczni świadkowie potwierdzają fakt umieszczenia przez nich ładunków wybuchowych oraz ich zatrzymanie. W zakazanej w Rosji książce pt. „Wysadzić Rosję, napisanej przez Jurija Fielsztinskiego i byłego funkcjonariusza FSB (otrutego przez rosyjskie służby radioaktywnym polonem $210 \mathrm{w}$ Wielkiej Brytanii w $2006 \mathrm{roku}^{61}$ ) Aleksandra Litwinienkę, pt. dowiedziono, że agenci FSB przeprowadzili zamachy, które były oficjalnym powodem usprawiedliwiającym militarną pacyfikację Czeczenii. Autorzy wykluczyli inspirowanie zamachów na rzecz bezpośredniego działania - według ich wersji FSB samo podkładało bomby ${ }^{62}$. Napisali, że kradzież nieznacznych ilości mieszanki heksogenu z trotylem nie należała do łatwych. Łatwe było wywiezienie jej ciężarówkami, jednak niezbędne były właściwe pozwolenia, co wiązało się z pozostawieniem nietrudnych do wykrycia śladów, które mogłyby skierować śledczych prosto do FSB. Po zamachach terrorystycznych wielu przedstawicieli rosyjskiego przemysłu militarnego twierdziło, że kradzież tak dużych ilości ładunków wybuchowych mogła się odbyć tylko przy współdziałaniu wysoko postawionych ludzi. 15 września 1999 roku Władimir Kozłow potwierdził, że przyczyną wybuchu przy ulicy Gurjanowa (zamach z 8 września) nie była pirotechniczna mieszanka domowej roboty, ale substancja wybuchowa pochodzenia przemysłowego ${ }^{63}$. Toteż $\mathrm{w}$ celu zmylenia uczciwej części funkcjonariuszy śledczych i dociekliwych dziennikarzy, agenci FSB przekazali mediom wersję, że w rzeczywistości powodem wybuchu był nawóz mineralny - saletra amonowa ${ }^{64}$. Jej nabywanie, przechowywanie i transportowanie było w pełni legalne, a przede wszystkim można $\mathrm{z}$ niej w prosty sposób wyprodukować bombę - trzeba jedynie dodać trotylu, heksogenu albo proszku aluminiowego, żeby zamieniła się w silny materiał wybuchowy. Jednak taka substancja wymaga skomplikowanego detonatora nie będącego $\mathrm{w}$ zasięgu możliwości konstrukcyjnych każdego terrorysty ${ }^{65}$.

$\mathrm{Na}$ początku rozpowszechniano wersję z heksogenem ponieważ same zamachy zostały przeprowadzone przez jedną grupę funkcjonariuszy FSB, analizę sporządziła grupa druga, a propagandowa strona zamachów należała do trzeciej. Pierwsza wypełniła swoją terrorystyczną misję, z wyjątkiem Riazania. Druga z łatwością zbadała, że zamachowcy wykorzystali heksogen. Trzecia nagle zorientowała się, że w Rosji heksogen wytwarza się jedynie w zamkniętych zakładach wojskowych, a co się z tym wiąże, łatwo ustalić nabywcę i czas zakupu substancji. Należy pamiętać, że moskiewskie

61 K. Kurczab-Redlich, Wowa,..., op. cit., s. 724.

62 A. Litwinienko, J. Felsztinski, op. cit.

63 Ibidem, s. 159.

64 Ibidem.

65 Ibidem. 
FSB najprawdopodobniej nie przewidziało scenariusza, w którym nie tylko zamach się nie powiedzie, ale ponadto agenci będą aresztowani, a kwatera główna zostanie namierzona. W ten sposób można wytłumaczyć sprzeczne wersje i nieporadne działania FSB - improwizowaniem $z$ braku gotowego planu reagowania wtedy wybuchła panika. Zaledwie trzy dni zajęło usunięcie wszystkich pozostałości po wysadzonych budynkach, a w mediach powtarzano wersję o saletrze amonowej. Aleksander Szagako - pierwszy zastępca dyrektora II Departamentu Obrony Porządku Konstytucyjnego i Zwalczania Terroryzmu (czyli Zarządu K) oraz Zarządu Operacyjno-Śledczego FSB, 16 marca 2000 roku w trakcie konferencji prasowej wydał następujące oświadczenie: „(...) w wyniku badania kryminalistycznego przeprowadzonego przez ekspertów z FSB, Rosja otrzymała właśnie potwierdzenie, że skład chemiczny materiałów wybuchowych użytych w Moskwie, skład chemiczny materiałów wybuchowych znalezionych w piwnicy domu przy ulicy Borisowskije Prudy [znajdował się przy niej ostatni blok, który zamierzano wysadzić] oraz skład chemiczny materiałów wybuchowych znalezionych 4 września w Bujnaksku w samochodzie ZIŁ-130 są identyczne. Oznacza to, że w skład wszystkich tych substancji wchodzą saletra amonowa i proszek aluminiowy. W niektórych przypadkach stwierdzono też domieszkę heksogenu albo trotylu" ${ }^{\prime 66}$.

Służby musiały jeszcze ustalić, skąd pochodzi saletra amonowa wykorzystana do przeprowadzenia zamachów. Podczas tej samej konferencji generał Zdanowicz przedstawił rozwiązanie: „Czy doszło do kradzieży tej niebezpiecznej substancji z państwowych fabryk, gdzie produkuje się je, korzystając ze specyficznych technologii?" 67 , zapytał, natychmiast udzielając odpowiedzi - „Mogę od razu odpowiedzieć, że nie, a przynajmniej do śledczych nie dotarły takie informacje" 68 . Litwinienko i Fielsztinski w książce skomentowali, że nie było możliwości ustalenia, kto sprzedał i kupił saletrę amonową użytą w zamachach terrorystycznych - było jej w Rosji i Czeczenii zwyczajnie za dużo. Proszek aluminiowy, heksogen i trotyl znajdowały się w każdym składzie wojskowym, a FSB i Naczelna Prokuratura Wojskowa poprzez media kilkakrotnie informowały o kradzieży nieznacznych ilości, czego robienie było rzeczywiście możliwe. Zdaniem autorów opinia publiczna była dezinformowana, co do substancji chemicznych wykorzystanych do przeprowadzenia zamachów, ponieważ FSB usiłowała obronić się przed podejrzeniami, że jej agenci odpowiadają za zaplanowanie i przeprowadzenie operacji terrorystycznych ${ }^{69}$.

Ostatnim zadaniem stojącym przed FSB było znalezienie w Czeczenii zmagazynowanych nawozów sztucznych. O rozwiązaniu tego problemu,

66 J. Felsztinski, W. Pribyłowski., op. cit.; A. Litwinienko, J. Felsztinski, op. cit., s. 160.

67 A. Litwinienko, J. Felsztinski, op. cit., s. 160.

68 Ibidem, s. 161.

69 Ibidem, s. 160-161. 
które umożliwiło zamknięcie śledztwa, a nastąpiło kilka dni przed wyborami prezydenckimi, w trakcie konferencji wypowiedział się Szagako. Zwrócił uwagę, że funkcjonariusze FSB w czeczeńskim mieście Urus-Martana dwa miesiące wcześniej dokonali odkrycia ośrodka szkoleniowego dla terrorystów, gdzie składowano 5 ton saletry amonowej. Znaleziono tam również urządzenia detonujące rezultaty analizy kryminalistycznej wykazały, że takie same jak te przechwycone w ciężarówce ZIŁ-130 w Bujnaksku oraz w piwnicy bloku przy ulicy Borisowskije Prudy w Moskwie ${ }^{70}$. Do konstrukcji detonatorów wykorzystano elektroniczne zegarki marki Casio (przerobione na urządzenia opóźniające detonację) i użyto jednakowego rodzaju diód elektroluminescencyjnych oraz identycznych płytek drukowanych, nawet przewody łączące podzespoły miały takie same kolory. W związku z czym Szagako poinformował, że kilka dni przed konferencją agenci FSB w Czeczenii przeszukujący poległego partyzanta trafili na kilka urządzeń zegarowych ${ }^{71}$. Wyniki specjalistycznego badania pokazały, że również $\mathrm{w}$ tym przypadku urządzenia były skonstruowane identycznie, jak te znalezione w ZIŁ-130 w Bujnaksku i w piwnicy przy Borisowskije Prudy ${ }^{72}$. Według Szagako w czeczeńskiej wiosce Duba-Yurt funkcjonariusze FSB przeszukali w marcu mieszczący się na skraju osady budynek, w którym znaleziono arabskie wydania podręczników wysadzania budowli, układania min i szeroko pojętego szkolenia wojskowego; znajdowały się tam też instrukcje obsługi zegarków Casio $^{73}$. W tym samym miesiącu agenci FSB w osadzie Cziri-Jurt w Czeczenii na terenie ogrodzonego żelaznym płotem, także stojącego na uboczu budynku, zauważyli, zidentyfikowali i zabezpieczyli 50 worków zawierających saletrę amonową - około 2,5 tony substancji wybuchowej ${ }^{74}$.

Wreszcie 11 marca 2000 roku moskiewskie czasopismo FreeLance Bureau otrzymało list zatytułowany „Wysadziłem Moskwę”, tak wyglądał jego początek: „Tak, to ja wysadziłem w powietrze budynek przy ulicy Gurjanowa w Moskwie. Nie jestem ani Czeczenem, ani Arabem. Nazywam się Władimir Kondratiew, jestem rodowitym Rosjaninem i majorem Federalnej Służby Bezpieczeństwa, a dokładniej pracownikiem ściśle tajnego oddziału K-20. Oddział ten powołano do życia wkrótce po podpisaniu porozumienia chasawjurckiego. Otrzymaliśmy zadanie planowania i wykonywania operacji dyskredytujących Republikę Czeczeńską tak, aby nie dopuścić do jej międzynarodowego uznania. W tym celu przyznano nam rozległe uprawnienia oraz dostęp do praktycznie nieograniczonych środków technicznych i finansowych"75. FSB zostało poinformowane o przesył-

70 Ibidem, s. 161; J. Felsztinski, W. Pribyłowski, op. cit.

71 A. Litwinienko, J. Felsztinski, op. cit., s. 161.

72 Ibidem.

73 Ibidem, s. 162; J. Felsztinski, W. Pribyłowski, op. cit.

74 A. Litwinienko, J. Felsztinski, op. cit., s. 161-162.

75 A. Zechenter, op. cit.; A. Litwinienko, J. Felsztinski, op. cit., s. 138-139. 
ce. Kondratiew opisał także jak werbowano więźniów kaukaskiego pochodzenia, którzy mieli się dopuszczać w Czeczenii porwań obcokrajowców w zamian za wolność. „Nasi podwładni poradzili sobie doskonale” - tymi słowami Autor skomentował zamordowanie m.in. brytyjskich i holenderskich obywateli ${ }^{76}$. Następnie przyznał: „W czerwcu ubiegłego roku nasz oddział otrzymał nowe zadanie: wzbudzać w Rosji nienawiść do Czeczenii i Czeczenów. Metodą burzy mózgów opracowaliśmy kilka sposobów. Podczas jednej z takich sesji wymyśliliśmy m.in. akcję rozprowadzania w kraju ulotek z groźbami Czeczenów (...), wysadzanie budynków mieszkalnych. Propozycje te przekazaliśmy dowództwu FSB, które wybrało ostatni pomysł jako najskuteczniejszy i dało nam zielone światło do jego realizacji. Zaplanowaliśmy ataki w Moskwie, Wołgodońsku i Riazaniu (...). Wybrane zostały konkretne budynki, odpowiedni materiał wybuchowy, obliczono też potrzebną jego masę. Operacja otrzymała kryptonim «Hiroszima»"77. Efekt zamachu przy ulicy Gurjanowa przesądził o dalszych losach Kondratiewa - tak opisał swoje doświadczenie: „(...) wysadziłem rosyjski dom i zabiłem Rosjan, a rosyjskie kobiety pochylone nad ciałami rosyjskich ofiar przeklinały sprawcę w moim ojczystym języku. Stojąc wśród nich fizycznie czułem, jak otaczają mnie ich klątwy, jak przenikają mój umysł i ciało. Byłem przeklęty"78.

\section{Skutki włączenia Czeczenii do Federacji Rosyjskiej}

Krystyna Kurczab-Redlich książkę „Wowa, Wołodia, Władimir. Tajemnice Rosji Putina" poświęciła pięciu osobom zamordowanym przez putinowski reżim, z których cztery zginęły posiadając dowody przeprowadzenia przez FSB wszystkich powyższych zamachów terrorystycznych. Wszczęta w wyniku tych zamachów i ofensywy Basajewa w Dagestanie, II wojna czeczeńska została tym razem przez Rosjan wygrana. Dzięki niej Putin wykreował się na obrońcę integralności terytorialnej Rosji i strażnika rosyjskiego honoru - ze stosunkowo mało znanego szefa FSB stał się dowódcą walki z czeczeńskim terroryzmem. Jednak Kurczab-Redlich twierdzi, że wszystkie wygrane przez niego wybory prezydenckie były sfałszowane (przykładowo w Czeczenii w 2012 roku zagłosowało na niego 99,73 procent wyborców, przy frekwencji wynoszącej 99,59 procent) $)^{79}$.

Po wojnie prezydentem Czeczenii został Achmad Kadyrow. Wtedy pojawił się termin „czeczenizacja Czeczenii”, czyli przejmowanie wpływów i władzy przez związanych z Kremlem Czeczenów. Achmad był muftim

76 Ibidem.

77 Ibidem.

78 Ibidem.

79 K. Kurczab-Redlich, Wowa,..., op. cit.; tvn24.pl/swiat/99-proc-na-putina-frekwencja-99-proc-ra202663-3494106 (18.03.2020). 
sunnickim teologiem i muzułmańskim prawnikiem, udzielającym konsultacji i porad prawnych w odpowiedzi na zapytania ze strony osób prywatnych, instytucji i urzędów (nie interpretował szariatu, a jedynie opierał się na istniejącym prawie $)^{80}$. Bardzo pozytywnie zapisał się w świadomości Czeczenów w trakcie I wojny. Problem polegał na tym, że Putin szukając odpowiedniego Czeczena zwrócił się ku Achmadowi, ponieważ ten już od lat 70. był współpracownikiem KGB. Powiązanie nie przeszkodziło mu w trakcie konfliktu, co pokazuje, że wówczas taki agent mógł aktywnie zwalczać Rosję, tocząc przeciwko niej działania bojowe. Jednak należy wziąć pod uwagę, że ówcześnie Rosjanie przechodzili przez tzw. wielką smutę i panował chaos. Pomimo, że w dowództwie i na czele znajdowało się wielu pracowników KGB, nie mieli takich możliwości, jakimi później dysponował Putin. Kurczab-Redlich uważa, że wraz z rozwojem Rosji zmieniła się służba bezpieczeństwa, która stała się mniej brutalna, a bardziej wyrafinowana. Twierdzi, że zmienił się styl myślenia: w pewnym momencie było już mniej przemocy fizycznej, a więcej putinizmu, czyli szukania powodów i sytuacji, którymi można szantażować, zastraszać i manipulować. Jej zdaniem siłą Putina było także doprowadzenie do tego, iż w końcu służby cywilne zaczęły górować nad wojskowymi. W czasach sowieckich - poza momentem Jurija Andropowa, kiedy KGB było bardzo silne - istniała między nimi nieustanna konkurencja ${ }^{81}$.

Achmad został współpracownikiem Kremla, ale nie zapominając, że jest również Czeczenem, w pewnym momencie zaczął bronić spraw swojego narodu przeciwko nie tyle władzy w Moskwie, co rosyjskim generałom, którzy wywozili z Czeczenii tony ropy, przez co kraj nie mógł się wzbogacić i odbudować po obydwu wojnach. 4 maja 2004 roku powiedział w telewizji NTW, że od teraz Czeczenia przejmuje całkowitą władzę nad swoją ropą - sama będzie ją kontrolować i nią rządzić ${ }^{2}$. Achmad zginął w zamachu 9 maja tego samego roku podczas świętowania Dnia Zwycięstwa na stadionie w Groznym, wskutek eksplozji materiału wybuchowego, który został wmurowany pod trybunę honorową. Tydzień później zorganizowanie zamachu przypisał sobie Szamil Basajew, którego zdaniem celem ataku byli zdrajcy Czeczenii, a on sam działał $\mathrm{w}$ imię prawa islamu ${ }^{83}$. Oprócz przedstawicieli sił bezpieczeństwa (m.in. generała Aleksandra Baranowa wówczas dowódcy armii rosyjskiej w Czeczenii, który stracił nogę) i prorosyjskich polityków, ofiarami stały się także osoby postronne ${ }^{84}$. Zabójstwo Achma-

80 Encyklopedia.pwn.pl/haslo/mufti;3944189.html (29.02.2020).

81 K. Kurczab-Redlich, Wowa,..., op. cit.; K. Kurczab-Redlich, Głową..., op. cit.; K. Kurczab-Redlich, Pandrioszka, op. cit.; W. Jurasz, K. Kurczab-Redlich, op. cit.

82 K. Kurczab-Redlich, Wowa,..., op. cit., s. 579.

83 N. West, Encyclopedia of Political Assassinations, Lanham 2017, s. 117.

84 K. Kurczab-Redlich, Wowa,..., op. cit.; K. Kurczab-Redlich, Głową..., op. cit.; K. Kurczab-Redlich, Pandrioszka, op. cit.; W. Jurasz, K. Kurczab-Redlich, op. cit. 
da zostało potępione przez Radę Bezpieczeństwa ONZ ${ }^{85}$. Na dwa tygodnie przed wybuchem nie wpuszczano żadnych przypadkowych ludzi w okolice stadionu. W dniu zamachu syn Achmada - szef służby ochrony ojca, nieodstępujący go Ramzan Kadyrow - z przyczyn zdrowotnych znalazł się w Moskwie. W momencie, w którym było już wiadomo, że Achmad zginął w zamachu, Ramzan w dresie został z hotelu natychmiast przewieziony na Kreml, gdzie Putin bardzo mu współczuł i przytulił go do piersi ${ }^{86} .10$ maja 2004 roku mianował Ramzana wicepremierem Czeczenii. Niebawem w Moskwie ciężarówka wjechała w samochód ówczesnego premiera Czeczenii, ciężko go raniąc - Ramzan przejął jego obowiązki ${ }^{87}$. Zdaniem Kurczab-Redlich prawdopodobnie wiedział, że ojciec zginie, a na pewno mógł się tego spodziewać. Do dzisiaj rządzi w Czeczenii, od 2007 roku (wtedy skończył wymagane konstytucyjnie 30 lat) już jako prezydent ${ }^{88}$.

Ramzan wyróżnia się dwoma atrybutami: był najgorzej wykształconym (miał za sobą kilka klas technikum; twierdzi, że posiada świadectwo ukończenia studiów w Dagestanie, ale nie potrafił odpowiedzieć Annie Politkowskiej, z jakiego prawa pisze pracę ${ }^{89}$ ) i najbardziej okrutnym z synów Achmada. Jest właścicielem koni arabskich, arsenału drogocennej broni i porusza się we flocie swoich luksusowych samochodów ${ }^{90}$. Lubi się spotykać z zachodnimi celebrytami - m.in. ze Stevenem Seagalem, Mike’em Tysonem, czy Gerardem Depardieu, który otrzymał od niego czeczeńskie obywatelstwo i drogie mieszkanie w Groznym. Ramzan wykazuje się przede wszystkim bezwzględnością i brutalnością ${ }^{91}$. Od kiedy zaczął rządzić wystarczy przejaw braku szacunku dla władzy, żeby trafić do więzienia (głównie jednego $\mathrm{z}$ dwóch, $\mathrm{w}$ tym prywatnego należącego do niego, wyposażonego w wymyślne narzędzia tortur) i być zamordowanym lub w lepszym wypadku torturowanym ${ }^{92}$. Jest właścicielem zoo, w którym trzyma lwy i tygrysy - wiadomo o dwóch przypadkach, kiedy wykorzystał zwierzęta do zabicia swoich wrogów (pozostałe są niepotwierdzone) ${ }^{93}$. Obywa-

85 News.un.org/en/story/2004/05/102992-deadly-terrorist-attack-chechen-president-condemned-annan-security-council (18.03.2020).

86 K. Kurczab-Redlich, Wowa,.., op. cit., s. 579; youtube.com/watch?v=y6_eWcDd-Ji (18.03.2020).

87 K. Kurczab-Redlich, Wowa,.., op. cit., s. 580.

88 Ibidem; K. Kurczab-Redlich, Wowa..., op. cit.; K. Kurczab-Redlich, Głowq..., op. cit.; K. Kurczab-Redlich, Pandrioszka, op. cit.; W. Jurasz, K. Kurczab-Redlich, op. cit.; szerzej: I. Jaszyn, Czeczenia Ramzana Kadyrowa, Krosno 2017.

89 K. Kurczab-Redlich, Wowa,..., op. cit., s. 580.

90 Ibidem, s. 582; I. Jaszyn, op. cit., s. 83-86; theguardian.com/world/2010/dec/01/ wikileaks-cables-ramzan-kadyrov-chechnya (18.03.2020); jalopnik.com/the-chechen-president-s-guns-supercars-and-3-000-000-5704390 (18.03.2020); youtube.com/ watch? $\mathrm{v}=\mathrm{c} 0 \mathrm{BuDsvXY} \mathrm{xg}(18.03 .2020)$.

91 W. Jurasz, K. Kurczab-Redlich, op. cit.

92 Ibidem; K. Kurczab-Redlich, Wowa,..., op. cit., s. 581.

93 Ibidem. 
tele Czeczenii pomiędzy 15 a 16 rokiem życia powinni wstępować do jego służby bezpieczeństwa, co wiąże się z wystąpieniem przeciwko opierającym się terrorowi. Niezastosowanie się do tego prawa jest traktowane jako przejaw nieposłuszeństwa ${ }^{94}$. W wywiadzie dla Kommiersanta z 2007 roku, na pytanie o istnienie w Czeczenii opozycji, Ramzan odpowiedział, że nie wie czym jest opozycja ${ }^{95}$.

Nowaja Gazieta opisała, jak jeden z szefów czeczeńskiej służby bezpieczeństwa, po dużej akcji aresztowania nie zakończonej wyrokiem sądowym, 26 stycznia 2017 roku osobiście zabił 27 osób ${ }^{96}$. W Czeczenii bardzo rzadko słyszy się o uczciwych procesach i wyrokach sądowych, a o tzw. kazniach natychmiastowo wykonywanych wyrokach śmierci słychać bardzo często. Takie egzekucje wyglądają $\mathrm{w}$ ten sposób, że podejrzany zostaje porwany przez uzbrojonych funkcjonariuszy (często ze swojego domu), a następnie torturowany (głównie prądem; zdaniem Kurczab-Redlich ta tortura jest współcześnie powszechnie stosowana także na posterunkach policji w Rosji ${ }^{97}$. Takie postępowanie ma na celu wydanie przez przesłuchiwanego każdego, kto mu przyjdzie do głowy; obecnie nie oskarża się o bycie czeczeńskim bojownikiem antyrządowym, ponieważ ich już praktycznie nie ma, ale o przynależność do Państwa Islamskiego. Jeśli torturowany nie zeznaje, jego dom jest podpalany, ktoś z jego rodziny - włączając kobiety - jest porywany i traktowany w ten sam sposób albo on sam zostaje zamordowany, a jego ciało jest znajdowane np. pod domem rodziców. W ten sposób opozycja w Czeczenii została całkowicie spacyfikowana ${ }^{98}$.

Współczesna Czeczenia nie odznacza się jedynie wewnętrznym terrorem - Kreml przekazuje Ramzanowi pieniądze na jej budowę, a Grozny już jest odbudowane. Do niedawna wszyscy pracujący w Czeczenii odprowadzali znaczną część dochodów na Fundusz im. Achmada Kadyrowa (będący prywatnym portfelem Ramzana) za sam fakt posiadania pracy ${ }^{99}$. Obecnie za sprawą niskiej podaży zatrudnienia np. nie można bez zapłacenia kilku tysięcy dolarów zostać pielęgniarką - stanowiska są nabywane drogą łapówek ${ }^{100}$. Rosyjscy opozycjoniści określają w mediach Czeczenię konglomeratem służb i bandytów, na których czele stoi Ramzan, będąc prawą ręką

94 I. Jaszyn, op. cit;; K. Kurczab-Redlich, Wowa,..., op. cit;; K. Kurczab-Redlich, Głowa..., op. cit.; K. Kurczab-Redlich, Pandrioszka, op. cit.; W. Jurasz, K. Kurczab-Redlich, op. cit.

95 Zobacz: „Kommiersant”, nr 103 (2007), Moskwa.

96 Telegraph.co.uk/news/2020/01/27/chechnya-duped-russian-human-rights-watchdog-presenting-siblings (19.03.2020).

97 W. Jurasz, K. Kurczab-Redlich, op. cit.

98 I. Jaszyn, op. cit.; K. Kurczab-Redlich, Wowa,..., op. cit.; K. Kurczab-Redlich, Głowq..., op. cit.; K. Kurczab-Redlich, Pandrioszka, op. cit.; W. Jurasz, K. Kurczab-Redlich, op. cit.

99 I. Jaszyn, op. cit., s. 8183; W. Jurasz, K. Kurczab-Redlich, op. cit.

100 W. Jurasz, K. Kurczab-Redlich, op. cit. 
Putina na całym Kaukazie ${ }^{101}$. Putin częściowo finansuje Czeczenię, zapewniając sobie spokój na południu Rosji, w czym nie przeszkadzają mu ani zachodnie państwa, ani ONZ ${ }^{102}$. Zdaniem Kurczab-Redlich Czeczenia została pokonana przede wszystkim moralnie - prześladowania i terror zmieniły mentalność narodu, który odstąpił od swoich kanonów. W przeszłości w Czeczenii nie wolno było podnieść ręki na starca, kobietę i dziecko (nieoficjalnie zdarzało się, że mężowie bili żony). Obecnie dopuszcza się torturowanie kobiet. Istnieją świadkowie sytuacji, w której strzelano do 4 letniej dziewczynki ${ }^{103}$. Światowa opinia publiczna zapomniała o tamtejszej rzeczywistości, tak jak zapomniała o tym, co się stało w Gruzji, o wydarzeniach w Syrii oraz o wojnie w Donbasie i aneksji Półwyspu Krymskiego ${ }^{104}$.

\section{Zakończenie}

Czeczeni podejmują próby i czasami uciekają ze swojego kraju. Gdy ministrem spraw wewnętrznych i administracji był Mariusz Błaszczak, w Polsce na granicy Brześć-Terespol kilkanaście tysięcy czeczeńskich obywateli usiłowało przejść na polską stronę, ale zostali zawróceni. W takiej sytuacji powrót do Czeczenii grozi śmiercią ${ }^{105}$. Ci, którym udało się przedostać do Polski uciekali na Zachód, gdzie poddawano ich ekstradycji. Ta z kolei zobowiązuje państwo przyjmujące do zagwarantowania bezpieczeństwa przyjmowanemu, włączając zakaz stosowania tortur, toteż Rosjanie z powodzeniem zaczęli zwracać się o niezwiązaną tym warunkiem deporta$\mathrm{cje}^{106}$. W sierpniu 2019 roku zamordowano w Wiedniu wroga Kadyrowa. Udowodniono, że za morderstwem stały rosyjskie służby. Dopiero po tym wydarzeniu Bundestag sprzeciwił się odsyłaniu Czeczenów, od czego już dawno odstąpił Interpol. Kanclerz Angela Merkel przy okazji jednego ze spotkań w formacie Normandzkim (rozmów przedstawicieli Rosji, Ukrainy, Niemiec i Francji, oficjalnie mających na celu rozstrzygnięcie wojny w Donbasie) powiedziała, że Niemcy nie będą wydawać wymaganych przez Rosję obywateli Czeczenii ${ }^{107}$. Polskie sądy także nie rozumiały realiów orzekając o ekstradycji. Jeden z wydanych przez Polskę Czeczenów według Kurczab-Redlich na pewną śmierć został uratowany wskutek starań polskich działaczy Fundacji Międzynarodowej Inicjatywy Humanitarnej z Marią Księżak na czele, będąc dosłownie ściągniętym z pokładu samolotu (jego

101 K. Kurczab-Redlich, Wowa,.., op. cit., s. 581.

102 I. Jaszyn, op. cit., s. 79-81.

103 W. Jurasz, K. Kurczab-Redlich, op. cit.

104 I. Jaszyn, op. cit.; K. Kurczab-Redlich, Wowa,..., op. cit.; K. Kurczab-Redlich, Głowa..., op. cit.; K. Kurczab-Redlich, Pandrioszka, op. cit.; W. Jurasz, K. Kurczab-Redlich, op. cit.

105 W. Jurasz, K. Kurczab-Redlich, op. cit.

106 Ibidem.

107 Ibidem. 
zapakowane rzeczy odleciały) ${ }^{108}$. Żadnego z polskich sędziów nie spotkały w związku z takimi wyrokami jakiekolwiek konsekwencje. Polskie służby odmawiając wpuszczania Czeczenów powołują się na brak wiz, jednak wiza nie powinna być wymagana, ponieważ wszystkim znajdującym się na granicy przysługuje prawo zwrócenia się z prośbą o tzw. opiekę międzynarodową. Czeczeni nie znają tego terminu, więc mówią, że uciekają przed prześladowaniami, ale nie spotykają się ze zrozumieniem ${ }^{109}$.

\section{Bibliografia}

\section{Książki i opracowania książkowe}

Anderson E. W., Global Political Flashpoint. An Atlas of Conflict, Nowy Jork 2000.

Fielsztinski J., Pribyłowski W., Korporacja zabójców. Rosja, KGB i prezydent Putin, Warszawa 2008.

Gessen M., Putin. Człowiek bez twarzy, Warszawa 2012.

Iwańczuk K., Geopolityka Kaukazu, w: Iwańczuk K., T. Kapuśniak (red.), Region Kaukazu w stosunkach międzynarodowych, Lublin 2008.

Jaszyn I., Czeczenia Ramzana Kadyrowa, Krosno 2017.

Kozłowski P., Obszar postradziecki w oficjalnych strategiach Federacji Rosyjskiej i Rady ds. Polityki Zagranicznej i Obronnej w: Winnicki Z. J., Baluk W., Tokarz G. (red.), Wybrane problemy badań wschodnich, Wrocław 2007.

Kuleba M., Szamil Basajew: rycerski etos a powinność żołnierska, Warszawa 2007.

Kurczab-Redlich K., Głowa o mur Kremla. Nowe fakty, Warszawa 2012.

Kurczab-Redlich K., Pandrioszka, Poznań 2000.

Kurczab-Redlich K., Wowa, Wołodia, Władimir. Tajemnice Rosji Putina, Warszawa 2016.

Litwinienko A., Fielsztinski J., Wysadzić Rosję, Poznań 2007.

Szukalski J., Konflikt w Czeczenii i jego wpływ na sytuację $w$ regionie Kaukazu, w: Iwańczuk K., Kapuśniak T. (red.), Region Kaukazu w stosunkach międzynarodowych, Lublin 2008.

West N., Encyclopedia of Political Assassinations, Lanham 2017.

Zakajew A., Ujarzmić lub wytrzebić, rękopis z archiwum Kurczab-Redlich.

\section{Czasopisma}

Gierańczyk W., Międzynarodowe uwarunkowania pozyskiwania ropy naftowej w rejonie kaspijskim, „Prace Komisji Geografii Przemysłu”, nr 10 (2010), Kraków.

„Kommiersant”, nr 103 (2007), Moskwa.

108 Ibidem.

109 I. Jaszyn, op. cit.; K. Kurczab-Redlich, Wowa,..., op. cit.; K. Kurczab-Redlich, Głowq..., op. cit.; K. Kurczab-Redlich, Pandrioszka, op. cit.; W. Jurasz, K. Kurczab-Redlich, op. cit. 
O'Loughlin J., Kolossov V., Radvanyi J., The Caucasus in a Time of Conflict, Demographic Transition and Economic Change, „Eurasian Geography and Economics", nr 2 (2007), Oxfordshire.

Zechenter A., Operacja „Hiroszima”, czyli Putin przejmuje władze, „Dziennik Polski”, nr 30.09 (2011), Kraków.

Wykaz stron internetowych

Britannica.com/topic/wahhabi (03.02.2020).

Cr.middlebury.edu/public/russian/bulgakov/public_html/nkvd.html ( 04.02.2020).

Edition.cnn.com/2013/09/09/world/europe/beslan-school-siege-fast-facts/index. html (02.02.2020).

Edition.cnn.com/2004/WORLD/europe/09/17/russia.beslan (02.02.2020).

Encyklopedia.pwn.pl/haslo/mufti;3944189.html (29.02.2020).

Eur-lex.europa.eu/LexUriServ/LexUriServ.do?uri=CELEX:32003R1607:EN:HTML (02.02.2020).

Henryjacksonsociety.org/wp-content/uploads/2018/06/1412-Whos-Blowing-Up-Russia.pdf (02.02.2020).

Jalopnik.com/the-chechen-president-s-guns-supercars-and-3-000-000-5704390 (18.03.2020).

Minenergy.gov.az/en/neft/baki-novorossiysk-neft-kemeri (07.08.2020).

News.un.org/en/story/2004/05/102992-deadly-terrorist-attack-chechen-president-condemned-annan-security-council (18.03.2020).

Rferl.org/a/after-25-years-budyonnovsk-hostage-crisis-seen-as-horrific-harbinger-of-terror/30668760.html (02.02.2020).

Telegraph.co.uk/news/2020/01/27/chechnya-duped-russian-human-rights-watchdog-presenting-siblings (19.03.2020).

Theguardian.com/world/2010/dec/01/wikileaks-cables-ramzan-kadyrov-chechnya $(18.03 .2020)$.

Tvn24.pl/swiat/99-proc-na-putina-frekwencja-99-proc-ra202663-3494106 (18.03.2020).

Web.archive.org/web/20080216090707/http://usinfo.state.gov/ei/archive/2004/ jan/07-157373.html (02.02.2020).

Web.archive.org/web/20131128153520/http://www.un.org/sc/committees/1267/ aq_sanctions_list.shtml (02.02.2020).

Jurasz W., Kurczab-Redlich K., Podcast \#97 Polityka z ludzka twarza: Krystyna Kurczab-Redlich, odc. 97, storytel.com/pl/pl/books/1077943-podcast-97-polityka-z-ludzka-twarza-krystyna-kurczab-redlich (01.02.2020).

Wprost.pl/194718/marszalek-komorowski-odwiedzi-grob-gen-okulickiego.html (04.02.2020).

Valvo G.: Dagestan: Geopolityczne znaczenie najbardziej wysuniętej na południe republiki Rosji. geopolityka.org/komentarze/1321-dagestan-geopolityczne-znaczenie-najbardziej-wysunietej-na-poludnie-republiki-rosji (07.08.2020).

Youtube.com/watch?v=c0BuDsvXYxg (18.03.2020).

Youtube.com/watch?v=y6_eWcDd-Ji (18.03.2020). 
Zając P.: Geopolityczne znaczenie Czeczenii w polityce Federacji Rosyjskiej - geopolityka.net/geopolityczne-znaczenie-czeczenii-w-polityce-federacji-rosyjskiej (07.08.2020).

Abstrakt

Rosjanie przegrali I wojnę czeczeńską. FSB zorganizowała porwania zachodnich obywateli, które miały zmienić rzeczywisty wizerunek czeczeńskiego narodu w Rosji i na Zachodzie. Agent FSB Adam Denijew założył pierwszą organizację wahabicką w Czeczenii. Współpracujący z GRU Szamil Basajew przeprowadził w Rosji szereg zamachów terrorystycznych. Stopniowo czeczeński ruch narodowowyzwoleńczy został przekształcony w ruch dżihadystyczny. FSB przeprowadziła słynne zamachy bombowe w Rosji, które wraz z ofensywą lądową Basajewa w Dagestanie, stały się casus belli do rozpoczęcia wygranej przez Rosjan II wojny czeczeńskiej. Po zamachu na prezydenta Czeczenii - Achmada Kadyrowa władzę przejął jego syn, rządzący do dzisiaj dyktator Ramzan Kadyrow, który jest prawą ręką Władimira Putina na Północnym Kaukazie.

Słowa kluczowe: polityka, Rosja, Czeczenia, FSB, terroryzm

\section{The Backstage of the Russian Policy towards the Chechen Republic and its Consequences}

Abstract

The Russians lost the First Chechen War. Russia's federal security service (FSB) organised kidnappings of western citizens to change the real image of the Chechen people in Russia and the West. The FSB agent Adam Deniyev founded the first Wahhabi organisation in Chechnya. Shamil Basayev, who collaborated with Russia's military intelligence Service (GRU), carried out a series of terrorist attacks in Russia. Gradually, the Chechen national liberation movement was transformed into a jihadist movement. The FSB carried out the infamous bomb attacks in Russia, which, together with Basayev's land offensive in Dagestan, became the reason for starting the Second Chechen War, won by the Russians. After the attack on the president of Chechnya Akhmad Kadyrov, power was taken over by his son, the dictator Ramzan Kadyrov, who is still ruling today, and is Vladimir Putin's right-hand man in the North Caucasus.

Keywords: politics, Russia, Chechnya, FSB, terrorism 